\title{
Manufacturing Process Development of Health Supplement Containing Water Hyacinth (Eichhornia crassipes) Extract
}

\author{
Diah Indriani Widiputri*, Quincy Juventinus, Silvya Yusri, Febbyandi Isnanda \\ Pandiangan, Jimmy
}

Faculty of Life Sciences and Technology, Swiss German University, Tangerang, Indonesia *Corresponding author. Email: diah.widiputri@sgu.ac.id

\begin{abstract}
Water hyacinth (Eichhornia crassipes), WH, is an aquatic plant that usually lives on the surface of lakes, marshes or rivers and often considered to be a weed that brings many negative impacts for the aquatic ecosystem. Previous research has proven the presence of antioxidant activity in the extract of this plant, which can be very beneficial for human health. However, to commercially utilize the extract of this plant, several steps must be thoroughly studied and prepared. This work was aimed at the development of manufacturing process to produce health product containing water hyacinth extract, where all aspects including the product safety, the availability of the main raw material, the proper formula of the product, the potential production capacity and the estimation of product quality in terms of the antioxidant activity were simulated. Market research conducted prior to the process development showed that tablet form was preferred by most respondents. The material balance calculation completed following the process development showed a potential production capacity of 812 tablets per hour by utilizing $30 \mathrm{~kg} / \mathrm{h}$ of fresh WH leaves, with an expected antioxidant $\mathrm{IC}_{50}$ value of the product of $480.24 \mathrm{ppm}$, which should be very competitive when compared with other herbal supplements that are already commercially marketed.
\end{abstract}

Keywords: Eichhornia crassipes, herbal supplement, tablet formulation, water hyacinth.

\section{INTRODUCTION}

Water hyacinth (WH) is known to be abundant in the environment, especially on a lake in the Indonesian regions such as Rawa Pening Lake in Central Java, Tondano Lake in North Sulawesi and Limboto Lake in Gorontalo. Due to its rapid growth on the surface of water and the fact that they consume nutrients such as nitrogen and phosphorus, this plant has been considered as a weed that harms aquatic life in many areas. They give a negative impact on the water where they grow by blocking the channels for irrigation, restricting the access to the river, destroying natural wetlands, eliminating native aquatic plants, less infiltration of sunlight, shifting the temperature of the water, and changing the $\mathrm{pH}$ and the oxygen content in the water [1].
In contrast to their disadvantages, WH has been proven to have antioxidant content. Previous studies have analysed antioxidant activities in extracts from its leaves and other parts of the plants. In the leaves, the ethanolic extract showed good 2,2-Diphenyl-1-Picrylhydrazyl hydrate (DPPH) radical scavenging activities, with an $\mathrm{IC}_{50}$ of $55.76 \pm 6.73 \mathrm{ppm}$ [2]. A further study performed a stability testing on the antioxidant activity of water hyacinth leaves powder extract and showed a shelf life of 35.51 days under refrigeration $[2,3]$.

With this knowledge, it becomes very promising to utilize WH leaves as a health product ingredient that offers herbal antioxidant supplements for the human body. However, to be utilized as a health product ingredient, the safety of this extract for an application in products for human consumption must be ensured in the first place. Moreover, prolonging the stability of the 
extract is necessary, since with a shelf life of around 35 days, it is still very limiting for this ingredient to be applied commercially. In addition to it, the production of this health product on an industrial scale will require a process development to define all necessary processing steps and operating conditions, to produce the health supplement with the expected antioxidant activity. Hence, this work was aimed at developing the conceptual design of the health supplement containing WH extract production process, by first ensuring the toxicity level of this extract.

\section{MATERIALS AND METHOD}

The WH plants used in this research were taken from Lake Situ Cipondoh, Tangerang. The chemicals were merely used for the extraction process, the analysis of total phenolic content and 2,2-Diphenyl-1Picrylhydrazyl hydrate (DPPH) scavenging for the determination of antioxidant activity of the extract; these were ethanol (Mallinckrodt, United Kingdom), gallic acid (Merck, Germany), DPPH (Sigma-Aldrich, USA), Folin-Ciocalciteau's reagent (Merck, Germany), sodium carbonate (Sigma-Aldrich, UK).

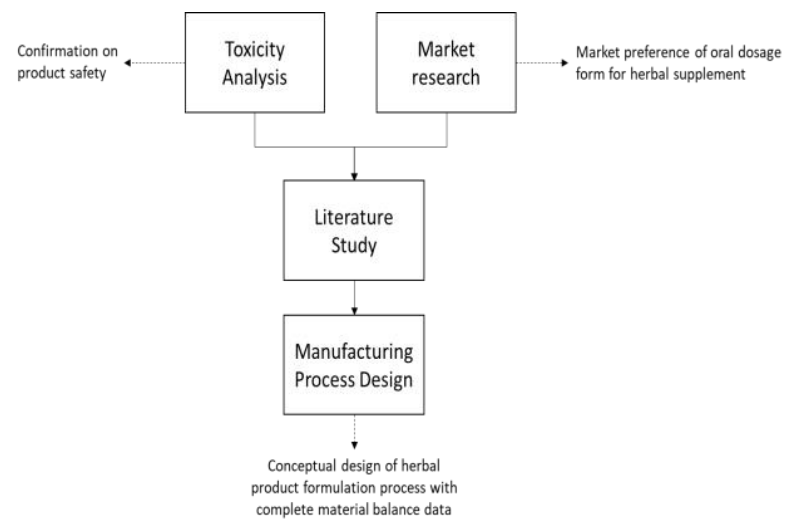

Figure 1. Research design flowchart

Figure 1 shows process design research that was conducted. The process is divided into four main stages which were the simplified market research to determine the desired form of the end-product, followed by literature study to gather information in the formulation of the health supplement and also to set several assumptions for calculation of material balances, so that afterwards the process equipment for the manufacturing process can be selected. Prior to all steps, toxicity analyses were conducted, in order to confirm that the WH extract is safe to be developed as a product for human consumption.

\subsection{Toxicity Analysis}

The study about safety of WH extract has actually been performed in a previous work [2], in the form of heavy metal content analysis, showing no detection of heavy metal content in all extracts produced in that work, which can be assumed to be very low to none. However, to have further confirmation about the product safety before it is applied on a product to be consumed by humans, toxicity analysis by means of brine shrimps mortality assay were performed in this work. The results of such tests will provide the information in the form of $\mathrm{LC}_{50}$ (lethal concentration 50), which is the concentration of the extract, at which $50 \%$ of the brine shrimp population can no longer live. A value of $\mathrm{LC}_{50}$ of smaller than $1,000 \mathrm{ppm}$ is to be considered toxic [4].

The toxicity analysis using brine shrimp's bioassay analysis was performed in 2 stages, the first stage was conducted at Swiss German University (SGU) internal laboratory to check the toxicity of WH liquid extract. The second stage of brine shrimp's bioassay analysis was conducted at an external laboratory, which was the IMERI Laboratory, Faculty of Medicine, University of Indonesia. The latter was to check the toxicity of pulverized WH extract.

The mortality rate of brine shrimps was calculated for each concentration using Equation (1) and (2) [5,6].

observed Mortality (\%) $=\frac{n \text { Death Shrimp Larvae }}{n \text { Total Shrimp Larvae }} \times 100 \%$

The mortality was corrected using Abott's formula:

$$
P t=\frac{(P o-P c)}{(100-P c)} \times 100 \% P t=\frac{(P o-P c)}{(100-P c)} \times 100 \%
$$

where, Po is observed mortality, Pc is control mortality, and $\mathrm{Pt}$ is the corrected mortality.

The powder extract samples used in the toxicity analysis at IMERI Laboratory were variated based on the extraction temperature of $\mathrm{WH}$ leaves and storage temperature. In order to produce the powder extract, the liquid extract were spray-dried, using encapsulating agents (equal mixture of maltodextrin and Arabic gum) with mass ratio of $1: 1$ of the total soluble solids (TSS) to total mass of encapsulating agents [3].

\subsection{Market Research}

The market research was conducted by using a questionnaire method using Google Form as a medium to conduct the survey. Before the market research was broadcasted through social media platforms, several parameters were considered to ensure that only relatable questions are listed. This market research was aimed to find out about the market preferences such as the form of the oral dosage form, types of the dosage form, and market's familiarity to herbal products especially to $\mathrm{WH}$ as herbal ingredient. Two hundred (200) responses were targeted, to fulfil at least $20 \%$ of the most reputable publications rule of thumb which is 1,000 respondents or 
around 3\% margin of errors [7]. The data from the questionnaire were assessed to separate the valid answers from the insignificant ones.

The results of this market research became the pillar of the process design to be developed later, since the form of the end product must be determined first according to the majority of the preferences obtained from this survey.

\subsection{Conceptual Design of Herbal Product Formulation Process}

In this process, the formulation is conducted after the end-product of the process design has been determined from the data assessment process. The formulation of the end-product involves determining the composition ratio for each ingredient. The main active pharmaceutical ingredient (API) is the bio compound with antioxidant activities that is composed in the WH leaves extract.

One of the most crucial considerations for determining the main API composition is the daily intakes of antioxidants for a dietary supplement for humans (effective dose and lethal dose). Secondly, the excipients to be added must also be selected, based on several considerations such as dietary oral dosage form. The type and composition of the excipient in the product must be considered to maintain the stability of the product without reducing the expected dosage of each intake.

Process flow diagram (PFD) of the developed process was then made to show the flow of the whole process from the raw materials until the desired end-product is obtained. After the development of the PFD, material balance calculation was performed to estimate the material flows when the process is to be operated in industrial scale.

\section{RESULTS AND DISCUSSION}

\subsection{Toxicity Analysis Result}

The toxicity test by means of brine shrimp lethality assay was performed by using a population of brine shrimps of 10 and in triplicates, in the concentration of extract range in between $\pm 10-1,000 \mathrm{ppm}$.

\subsubsection{Toxicity Analysis Results of Liquid Water Hyacinth Extract}

The toxicity test was carried out triplicates for each WH leaves extract. Each extract requires 9 test tubes for sample and 3 test tubes as control. For the control, 100 $\mu \mathrm{L}$ of dimethyl sulfoxide (DMSO) was added to each tube containing $4.9 \mathrm{~mL}$ of brine. The stock solution of WH extract concentration was serial diluted to 1000, 100 and $10 \mathrm{ppm}$ by using brine in test tubes. Each test tube was added with $100 \mu \mathrm{L}$ of dimethyl sulfoxide (DMSO), a drop of yeast solution and 10 shrimp larvae (nauplii).
Afterwards, the control and the sample were added with brine until the volume reached $5 \mathrm{ml}$. The observation of dead shrimp larvae was carried out in 24 hours. The mortality rate was calculated for each concentration using Equation (1) and (2) as explained in Materials and Method.

The data were then plotted into a logarithmic graph and linear regression equation was obtained. The linear regression is used to calculate lethal concentration 50 $\left(\mathrm{LC}_{50}\right)$ value. If the extract's $\mathrm{LC}_{50}<1,000 \mathrm{ppm}$, it can be said the sample is toxic. Figure 2 show the mortality-\% of the population in different extract concentrations.

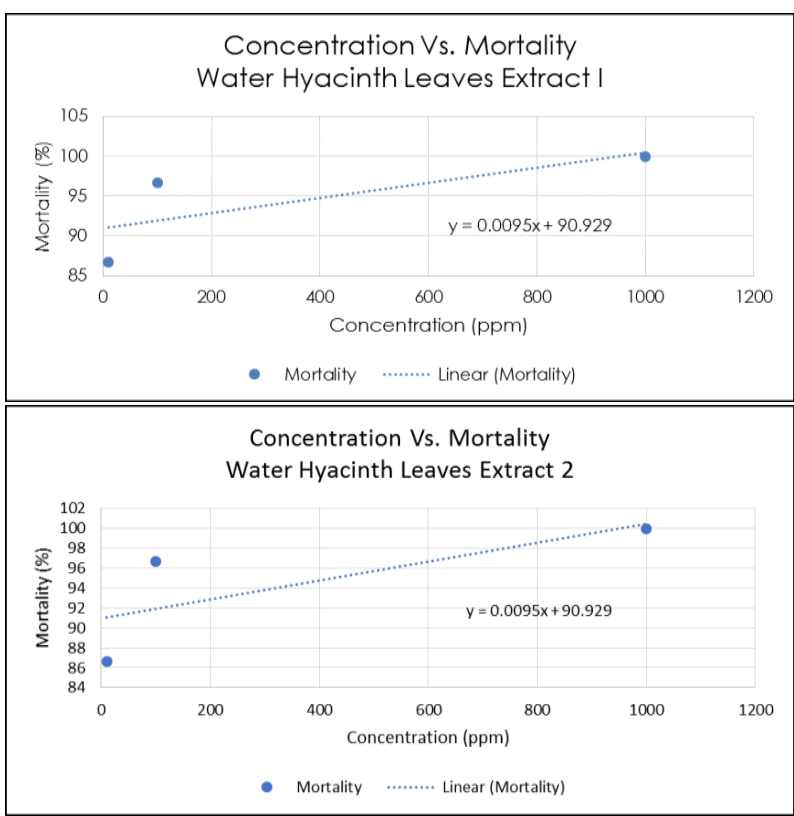

Figure 2 Effect of extract concentrations on mortality; analysis on liquid extracts 1 (top) and 2 (bottom)

The $\mathrm{LC}_{50}$ of the extract mixture could be calculated from the equation from Figure 2, where $y$-value is substituted with 50 and the $\mathrm{x}$-value at that point will be read as the lethal concentration in ppm. A value of $\mathrm{LC}_{50}$ $<1,000 \mathrm{ppm}$ means that the extract is toxic [4]. From the result, a negative value was obtained as the $\mathrm{LC}_{50}$, which means a high rate of mortality has happened even in 0 ppm concentration of the extract (or in the blank sample, which was the solvent of extraction used, a mixture between $96 \%$-ethanol and water by 1:1 ratio by weight). This showed that the brine shrimps could not live in the ethanol mixture used as the extraction solvent, even before any liquid WH extract was added.

In hatching brine shrimp eggs, different amounts of $70 \%$ ethyl alcohol are sometimes recommended to be used. The best to hatch the eggs is without using ethanol, with $49.31 \%$ success rate hatched eggs. With $0.1 \mathrm{~mL}$ of ethyl alcohol, it has slightly less success rate, which is $47 \%$. With $0.5 \mathrm{~mL}$ of ethyl alcohol, it has a success rate of $21.80 \%$ [8]. This shows that the increasing amount of ethyl alcohol used in hatching will decrease the success 
rate and might also affect the mortality of the shrimps. Hence, the liquid extract of WH leaves still containing ethanol as solvent is considered toxic according to this experiment result.

\subsubsection{Toxicity Analysis Results of Powder Water Hyacinth Extract}

Since from the previous toxicity test result there is an indication that the remaining ethanol in the WH liquid extract can cause the extract to be categorized as toxic, a further toxicity test was performed on the powder extract of WH leaves.

The brine shrimp lethality bioassay analysis on powder WH extract delivered results shown in Table 1. The seven variations of samples are different one from the other due to their production process and storage condition. The samples R1, R2 and R3 are powder extracts resulting from extractions at different temperatures, $30^{\circ} \mathrm{C}, 40^{\circ} \mathrm{C}$, and $50^{\circ} \mathrm{C}$, respectively. All three samples were stored in the refrigerator for the first 12 weeks after production. In order to produce powder extract, the liquid extract of these 3 conditions were spray-dried, using encapsulating agents (equal mixture of maltodextrin and Arabic gum) with mass ratio of 1:1 of the total soluble solids (TSS) to total mass of encapsulating agents.

Table 1 Results of brine shrimp lethality bioassay analysis of powder WH extracts

\begin{tabular}{ccccccccc}
\hline \multicolumn{10}{c}{ Brine Shrimps Mortality (\%) } \\
\hline $\begin{array}{c}\text { Concen- } \\
\text { tration } \\
(\mathbf{p p m})\end{array}$ & $\mathbf{R 1}$ & $\mathbf{R 2}$ & $\mathbf{R 3}$ & $\mathbf{R 4}$ & $\mathbf{R 5}$ & $\mathbf{T 1}$ & $\mathbf{T 2}$ & $\begin{array}{c}\text { Con- } \\
\text { trol }\end{array}$ \\
\hline 7.8 & 0 & 0 & 0 & 0 & 0 & 0 & 0 & 0 \\
\hline 15.25 & 0 & 0 & 0 & 0 & 0 & 0 & 0 & 0 \\
\hline 31.25 & 0 & 0 & 0 & 0 & 0 & 0 & 0 & 0 \\
\hline 62.5 & 0 & 0 & 0 & 0 & 0 & 0 & 0 & 0 \\
\hline 125 & 0 & 0 & 0 & 0 & 0 & 0 & 0 & 0 \\
\hline 250 & 0 & 10 & 0 & 0 & 0 & 0 & 0 & 0 \\
\hline 500 & 3.33 & 20 & 0 & 0 & 0 & 0 & 0 & 0 \\
\hline 1000 & 30 & 20 & 0 & 0 & 0 & 0 & 0 & 0 \\
\hline & & & & & & & & \\
\hline
\end{tabular}

Samples R4 and R5 were produced at $50^{\circ} \mathrm{C}$ using other variations of ratios (1:2 and $2: 1$, respectively) between encapsulating agents and the TSS of the sample. These two samples have also undergone storing at refrigeration temperature for the first 12 weeks after production. The sample $\mathrm{T} 1$ and $\mathrm{T} 2$ were the same extracts as R4 and R5 but were stored directly at room temperature after production.

Table 1 shows that only in sample R1 and R2 the mortality of the shrimps could be observed, which happened in the higher range of concentrations, starting at $500 \mathrm{ppm}$. All other samples did not show any mortality of brine shrimps in the concentration range up to 1,000 $\mathrm{ppm}$. As previously mentioned, extracts with $\mathrm{LC}_{50}$ values smaller than 1,000 ppm are considered as toxic, with following categorization: $\mathrm{LC}_{50}$ of $500-1,000 \mathrm{ppm}$ is low toxic, $100-500 \mathrm{ppm}$ is medium toxic, and $0-100 \mathrm{ppm}$ is highly toxic [4]. In order to confirm the value of $\mathrm{LC}_{50}$ from samples R1 and R2, plotting between the mortality values with ranging extract concentrations.

The data were then plotted into a logarithmic graph and linear regression equation was obtained. The linear regression is used to calculate lethal concentration 50 $\left(\mathrm{LC}_{50}\right)$ value. If the extract's $\mathrm{LC}_{50}<1,000 \mathrm{ppm}$, it can be said the sample is toxic. Figure 2 show the mortality-\% of the population in different extract concentrations was made, as can be seen in Figure 3.

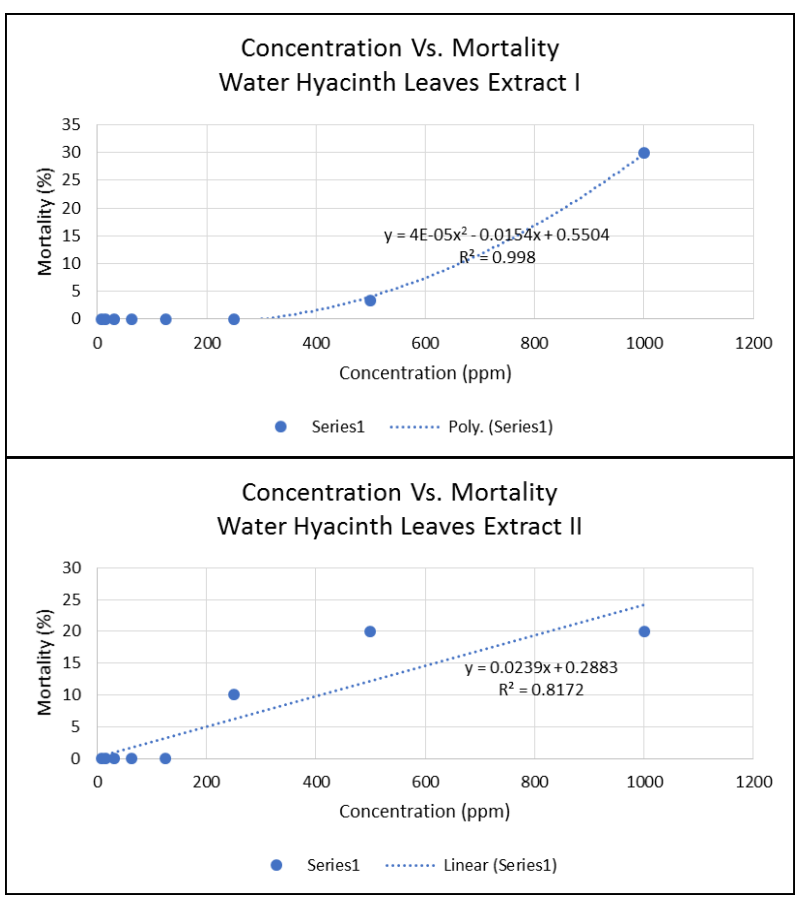

Figure 3 Effect of extract concentration of brine shrimp's mortality; powder extracts R1 (top) and R2 (bottom0

The $\mathrm{LC}_{50}$ values for samples $\mathrm{R} 1$ and $\mathrm{R} 2$ were using the trend line equations obtained from the plotting. It can be determined that for sample $\mathrm{R} 1$ the $\mathrm{LC}_{50}$ is $1,321 \mathrm{ppm}$, and is 2,080 ppm for sample R2, which give confirmation that even though mortality of shrimps was observed in these two samples, the $\mathrm{LC}_{50}$ values were high enough to be classified as non-toxic. This also confirmed the research by [9], stating that the $\mathrm{LC}_{50}$ of $\mathrm{WH}$ leaves powder is more than $16 \mathrm{~g} / \mathrm{kg}$ body weight. This is slightly above the National Standards of PRC which states that if $\mathrm{LC}_{50}$ of a chemical compound is above $15 \mathrm{~g} / \mathrm{kg}$ body weight, it should be considered to be acutely nontoxic.

A conclusion was made at this point, that powder WH extract is found to be non-toxic and is safe for further application in health products. However, the liquid extract should not be directly utilized as ingredients, at the very least, not until a re-examination is conducted to ensure its safety. 


\subsection{Market Research on Herbal Products}

The questionnaire was sent to approximately 400 people as the expected response rate is $50 \%$ of the people who receive the questionnaire form [10]. The number of respondents that have answered the questionnaire is concluded to be a valid number of respondents that could be used as data for the research. In order to have the valid information with $95 \%$ confidence and a maximum margin of error of $10 \%$, the required number of respondents calculated using an equation suggested by [11] is 96. The respondents that were willing to answer the questionnaire were 211 people and each respondent has their own preferences regarding the dosage form and familiarity of herbals. The respondents that answered the questionnaire varied from their age, jobs, and genders.

Based on Table 2, it can be seen that most of the respondents that answered the questionnaire are mostly men. However, based on the actual data of the market research the gender of the respondents is not significantly different from each other. Therefore, it is safe to say that the questionnaire was spread equally between the genders. While most of the respondents came from college students with the range of ages between $18-25$ years old which is because the spread of the questionnaire is conducted via social media which are believed to be used mostly by that range of age.

The respondents answered that the dosage form they mostly consumed is solid dosage form as well as the dosage form that they find comfortable to consume. According to the data, speculation was made. The availability of the dosage form in the market is mostly solid dosage form because it has more stability over the liquid dosage form and the solid dosage form is the easiest type to be manufactured. Due to this higher availability, the respondents might be more used to consuming solid dosage form rather than liquid dosage form.

Tablets are the type of solid dosage form that is mostly chosen by the respondents. The data show that the types of solid dosage form that are mostly chosen by the respondents are tablets and capsules which has only a 7\% difference in the answers. The same speculation was made, that tablets and capsules are the types of solid dosage form with higher availability in the market than other types. Capsules are mostly used for supplements especially herbal supplements and are also very suitable for this process design research. However, the endproduct form in this research was chosen to be tablets, following the biggest preference resulting from this survey. The familiarity of herbals shows that the most consumed type of herbal is ginger as ginger has been used as a seasoning and spices of many foods in Indonesia

while WH remains as the least type of herbal to be consumed by the respondents. The respondent's answers regarding the awareness of the WH plant prove that most of them are aware of the plant but they are unaware of its functions as an herbal ingredient, which leads to a lack of knowledge of what WH could possibly affect.

Along with this lack of awareness of WH beneficial function on health, the respondents' answers indicated that the market interest on the health supplement product is mostly in doubt to purchase herbal products containing WH extract. Therefore, before the health supplement containing WH extract is commercially marketed, a marketing strategy should be managed to educate the consumers about the health benefits that can be offered through consumption of WH extract.

\subsection{Formulation Process Development of the Health Supplement}

Solid dosage form with the type of tablets is chosen to be the end-product of this conceptual process design. The manufacturing process will be started by pre-treating the raw materials. The raw materials will undergo the process of washing, cutting, and drying. In these processes, the WH leaves will be washed to remove the dirt, then cut into smaller pieces to ease the process of drying [12].

Table 2 Summary of market research results

\begin{tabular}{|c|c|c|}
\hline Category & Majority Responses & Percentage \\
\hline Gender of the Respondents & Men & $54 \%$ \\
\hline Job of the Respondents & College students & $48 \%$ \\
\hline Range of Age & $18-25 \mathrm{y} / \mathrm{o}$ & $56 \%$ \\
\hline Most Consumed Dosage Form & Solid dosage form & $79 \%$ \\
\hline Most Comfortable Dosage Form & Solid dosage form & $69 \%$ \\
\hline Types of Solid Dosage Form & Tablets & $39 \%$ \\
\hline Consumption Rate of Supplements & Several times a week & $56 \%$ \\
\hline Mostly Consumed Types of Herbal & Ginger & $75 \%$ \\
\hline Least Consumed Types of Herbal & Water Hyacinth & $2 \%$ \\
\hline Respondents Beliefs on Herbal Efficacy & Believe in Herbal Efficacy & $62 \%$ \\
\hline Respondents Awareness on WH Plant & Aware & $73 \%$ \\
\hline
\end{tabular}


Respondents Awareness on WH Efficacy Respondents Interest on WH supplement

Table 3 Formula of Herbal Tablets [15, 16]

\begin{tabular}{ccccc}
\hline & & & Tablet Water & Tablet Bitter \\
Spinach & & $\begin{array}{c}\text { Gourd } \\
\text { Tmount (mg) }\end{array}$ & Amount (mg) \\
\hline $\begin{array}{c}\text { Types of } \\
\text { Materials }\end{array}$ & Water Spinach & Materials & Amourter Gourd & \\
\hline API & $\begin{array}{c}\text { Water Spinach } \\
\text { Extract }\end{array}$ & Bitter Gourd Extract & 72 & 100 \\
& Ceolus PH 101 & Avicel PH 101 & 338 & 435 \\
\hline Filler & Ceolus PH 101 & Gelatin & 338 & 30 \\
\hline Binding Agent & Amylum Manihot & Explotab & 75 & 25 \\
\hline Disintegrant & Magnesium Stearate & Aerosil & 10 & 5 \\
\hline Lubricant & Povidone K30 & Magnesium Stearate & 5 & 6 \\
\hline & TOTAL WEIGHT & & $\mathbf{5 0 0}$ & $\mathbf{6 0 0}$ \\
\hline
\end{tabular}

\subsubsection{Processing Steps to Produce Water Hyacinth Powder Extract}

The cut leaves will then be dried by using an oven or tray dryer as it is the most used unit operation to dry food products. Moreover, the tray dryer provides a constant drying temperature to ensure the homogeneity of the dried sample. The dried leaves then were ground to achieve a smaller particle size until it became a fine powder. The fine powder that is produced by the grinding process must have a diameter below $250 \mu \mathrm{m}$ to fulfil the requirement for the extraction process. Sieving method was also used to ensure the homogeneous particle size distribution.

The extraction process to extract the antioxidant content from $\mathrm{WH}$ powder will use a mixture of $96 \%$ ethanol and water in a 1:1 ratio by weight [3] at a temperature of $50^{\circ} \mathrm{C}$ with constant stirring for 3 hours. The extracted solution will then be dried by means of spray drying to remove the remaining solvent. The powder extract result will be the API (active pharmaceutical ingredients) in the health supplement formulation process being designed. This powder extract will be mixed with different excipients such as a filler, binder, disintegrant, and lubricant. The excipients selected for the formulation must be inert (does not react with the active pharmaceutical ingredient of the product) [13].

\subsubsection{Formulation of Herbal Supplements Containing Water Hyacinth Extract}

Several research regarding the formulation of health supplements in tablet form have proven that the formulation by using excipients could enhance the quality of the tablets such as the flowability and solubility [14]. Table 3 describes the formula of a health supplement in "formulation of tablet containing water spinach (Ipomoea aquatica F.)" [15]. The required ingredients in this formulation were the water spinach as the API, Ceolus PH 101 (Microcrystalline Cellulose) as a binding agent for the tablet, which also works as a filler, amylum manihot as the disintegrant, magnesium stearate as the lubricant to enhance the flowability of the tablet, and Povidone K 30 (polyvinylpyrrolidone (PVP)) as another binding agent.

Another formulation of herbal tablet containing bitter gourd (Momordica charantia L.) extract [16] also used a similar formula as described in Table 3 . The formulation of bitter gourd tablets used bitter gourd as the main the API, gelatine as the binding agent, Explotab (a modification of amylum from starch) as disintegrant for the tablet, Avicel PH 101 (microcrystalline cellulose) as the binding agent, aerosil and magnesium stearate as lubricant for the tablet to enhance further its flowability. Based on the information from literature listed in Table 3 , a selection of formula was made for the WH extract tablet, after several considerations. The selected formula is listed in Table 4.

Table 4 Formula of WH Health Supplement

\begin{tabular}{llc}
\hline \multicolumn{1}{c}{ Materials } & Function & Weight $(\mathbf{m g})$ \\
\hline WH $($ WH) Extract & API & 100 \\
\hline Lactose & Filler & 240 \\
\hline $\begin{array}{l}\text { Microcrystalline } \\
\text { Cellulose }\end{array}$ & $\begin{array}{l}\text { Binding } \\
\text { Agent }\end{array}$ & 100 \\
\hline Amylum Manihot & Disintegrant & 50 \\
\hline Magnesium Stearate & Lubricant & 10 \\
\hline Total Weight & & $\mathbf{5 0 0}$ \\
\hline
\end{tabular}

The main API of the product will be the WH extract with $100 \mathrm{mg}$ weight which will provide the antioxidant activity. While the rest of the mass of the tablet will be the excipients which are believed to be able to increase the stability of the product and therefore enhance its 
stability. Lactose as the filler will have a weight of 240 mg which is about half of the total size, and was chosen for its bland taste and low hygroscopicity. Since lactose has the characteristic to be low in hygroscopicity while
WH extract shows the opposite, lactose is believed to be able to decrease the overall product's hygroscopicity.

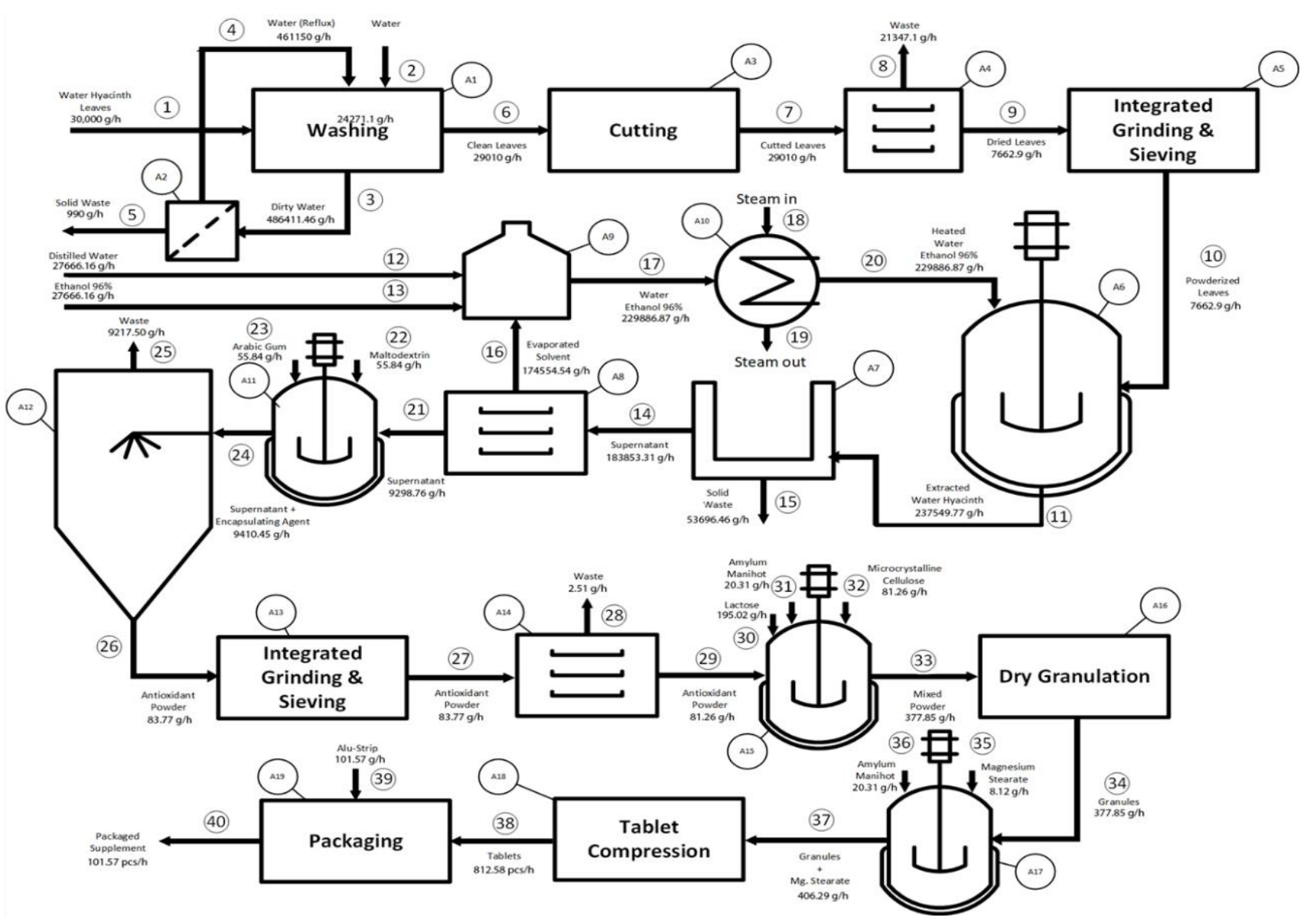

Figure 4 Process flow diagram (PFD) of WH tablet formulation

Lactose is also known to have excellent physical and chemical stability; hence, the stability of the product could be improved. The amount of lactose added is overweighting other excipients, since the increase in the proportions of lactose will increase the stability of the product [17].

Microcrystalline Cellulose has the characteristics of a binding agent which improves compaction, flowability enhancement, and content uniformity in dry granulation processes which use roller compaction methods. As much as $100 \mathrm{mg}$ of microcrystalline cellulose is added to add an adequate amount of cohesion to the powders for the process and to allow the tablet to disintegrate and dissolve upon ingestion. Normally binder is added to the formulation by $10-20 \%$ by mass of the tablets to be able to enhance the particle bond between each other [18].

Amylum manihot is added to the formulation as a disintegrant. Disintegrant should be added at the right amount of mass which is around $5-10 \%$ of the tablet mass. Above $10 \%$, the incompressibility of starch makes the tablet difficult to be compressed, while below $5 \%$ there will be insufficient disintegrant to be able to swell the tablet to disintegrate. The amount of disintegrant added to the formulation is $50 \mathrm{mg}$ which is $10 \%$ of the total mass of the tablet.

Magnesium stearate has a main function as a lubricant. A lubricant is added to the process at the last mixing process which has the purpose to enhance the flowability of the tablet. As much as $10 \mathrm{mg}$ is chosen as the weight of the lubricant because the involvement of lubricant is to coat the outer layer of the tablet and does not require to be in a large quantity. A large quantity of lubricant will smoothen the particles in the layer and will break the tablet apart in processing.

\subsubsection{Process Flow Diagram (PFD) and Material Balance Calculation}

The process is divided into 4 major stages which are pre-treatment, extraction, mixing, and granulation 
(Figure 4). In the pre-treatment process, the WH leaves are washed, reduced in size through cutting, dried, grinded, and sieved. The pre-treatment process is the process with the raw $\mathrm{WH}$ leaves is the input and ends with $\mathrm{WH}$ leaves powder. Afterwards, the extraction of WH leaves powder is performed using ethanol/water mixture as the solvent. The product will be the liquid WH extract which will directly go to the evaporation and spray drying process to remove most of the solvent remaining from the extract, to produce a powder $\mathrm{WH}$ extract.

After obtaining the powder WH extract, the mixing with the excipients will take place. In order to homogenize the mixture, a granulation process will be required, whose purpose is to enhance the particle size of the powder as well as increasing the flowability of the product. Figure 10 shows that $30 \mathrm{~kg}$ of $\mathrm{WH}$ leaves could produce $812.58 \approx 812$ tablets which are packaged into $101.57 \approx 101$ strips. As much as $30 \mathrm{~kg}$ of fresh WH leaves would be inserted every hour as the inlet of the raw materials and the production would take 24 hours in a day. Therefore, 19,502.04 $\approx 19,502$ tablets would be produced in one day of production which will be packaged into $2,437.75 \approx 2,437$ strips. The total phenolic content (TPC) contained in the WH leaves decreases over each process stage. Taking the initial TPC of the WH to be at $189.81 \mathrm{~g} / 30 \mathrm{~kg}$ of WH leaves and by the time the process has reached the end of the manufacturing process, the TPC will be 81.126 grams for every 812 tablets produced (Figure 5).

There are two processes that potentially reduced the TPC; these are the centrifugation process, which reduces the phenolic content by 78.12 grams and the spray drying process which reduces TPC by 30.56 grams. Both processes might not be efficient for maintaining TPC, but the processes are necessary for the manufacturing process and to remove the rest of the solvent from the extract, so that safety of the product can be ensured. Each tablet contains $100 \mathrm{mg}$ of WH extract which proven to have an antioxidant activity of $6.3071 \mathrm{mg}$ GAE, using the assumption that the TPC of the powder extract is 63.07 $\mathrm{mg} \mathrm{GAE} / \mathrm{g}$ powder while the $\mathrm{IC}_{50}$ of the powder extract shows the concentration of $306.75 \mathrm{ppm}$ [3].

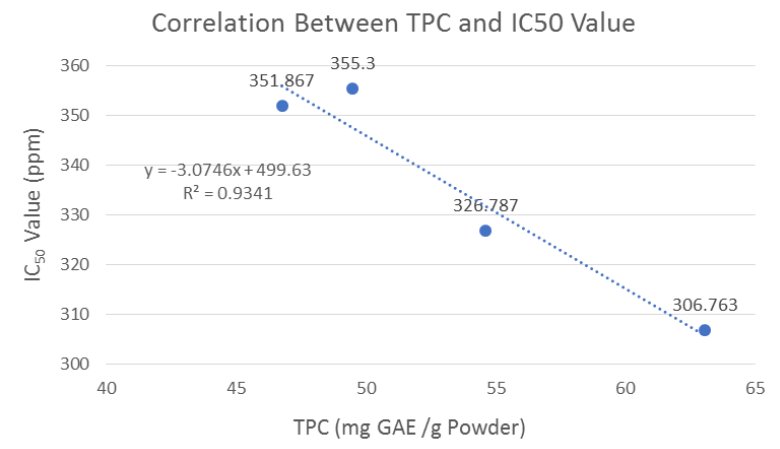

Figure 5 Correlation between $\mathrm{TPC}$ and $\mathrm{IC}_{50}$ value during stability analysis [3]

Table 5 Simulation of non-ideal processes outcome

\begin{tabular}{|c|c|c|c|c|}
\hline No & Non-ideal Process & Ideal Process & $\begin{array}{c}\text { Non-ideal Process } \\
\text { Outcome }\end{array}$ & Remarks \\
\hline 1. & $\begin{array}{l}\text { Washing (A1): } \\
\text { Assume there is } \\
29.3 \% \text { of phenolic } \\
\text { content loss due to the } \\
\text { dissolution of the TPC } \\
\text { of the WH leaves. }\end{array}$ & $\begin{array}{l}\text { Washing (A1): } \\
\text { There is no loss in } \\
\text { the TPC of the WH } \\
\text { leaves. }\end{array}$ & $\begin{array}{l}575 \text { tablets are produced } \\
\text { per hour, packaged in } 72 \\
\text { Alu-Strips. }\end{array}$ & $\begin{array}{l}\text { There is a huge change in the } \\
\text { production of health supplement as } \\
\text { the yield of the TPC from the } \\
\text { processes is decreased significantly. } \\
\text { The washing process decreases the } \\
\text { TPC from } 189.80 \mathrm{~g} / \mathrm{h} \text { to } 134.19 \mathrm{~g} / \mathrm{h} \text {. }\end{array}$ \\
\hline 2. & $\begin{array}{l}\text { Cutting (A3): Assume } \\
\text { there are } 3 \% \text { leaves } \\
\text { stuck between the } \\
\text { blades. }\end{array}$ & $\begin{array}{l}\text { Cutting (A3): } \\
\text { There are no leaves } \\
\text { stuck between the } \\
\text { blades. }\end{array}$ & $\begin{array}{l}787 \text { tablets are produced } \\
\text { per hour packaged in } 99 \\
\text { Alu-Strips. }\end{array}$ & $\begin{array}{l}\text { There is an alteration in the } \\
\text { phenolic content from } 189.80 \mathrm{~g} / \mathrm{h} \text { to } \\
182.59 \mathrm{~g} / \mathrm{h} \text { due to the differences in } \\
\text { mass in the processing. }\end{array}$ \\
\hline 3. & $\begin{array}{l}\text { Drying (A4): Assume } \\
\text { there is } 10 \% \text { loss in } \\
\text { phenolic content }\end{array}$ & $\begin{array}{l}\text { Drying (A4): } \\
\text { There is no loss in } \\
\text { the phenolic } \\
\text { content }\end{array}$ & $\begin{array}{l}731.45 \text { tablets are } \\
\text { produced per hour, } \\
\text { packaged in } 91 \text { Alu- } \\
\text { Strips }\end{array}$ & $\begin{array}{l}\text { There is a significant change in the } \\
\text { phenolic content of the drying } \\
\text { process from } 189.80 \mathrm{~g} / \mathrm{h} \text { to } 170.82 \\
\mathrm{~g} / \mathrm{h}\end{array}$ \\
\hline 4. & $\begin{array}{l}\text { Grinding (A5): } \\
\text { Assume there is } \\
1.41 \% \text { powder loss }\end{array}$ & $\begin{array}{l}\text { Grinding (A5): } \\
\text { Assume there is no } \\
\text { loss of powder }\end{array}$ & $\begin{array}{l}801 \text { tablets are produced } \\
\text { per hour packaged in } 100 \\
\text { Alu-Strips }\end{array}$ & $\begin{array}{l}\text { There are no big differences in the } \\
\text { process of production as it } \\
\text { decreases the phenolic compound } \\
\text { from } 189.80 \mathrm{~g} / \mathrm{h} \text { to } 187.13 \mathrm{~g} / \mathrm{h}\end{array}$ \\
\hline 5. & $\begin{array}{l}\text { Sieving (A5): Assume } \\
\text { there is } 0.83 \% \text { powder } \\
\text { loss }\end{array}$ & $\begin{array}{l}\text { Sieving (A5): } \\
\text { Assume there is no } \\
\text { loss of powder }\end{array}$ & $\begin{array}{l}806 \text { tablets are produced } \\
\text { per hour packaged in } 101 \\
\text { Alu-Strips }\end{array}$ & $\begin{array}{l}\text { There are no big differences in the } \\
\text { process of production as it } \\
\text { decreases the phenolic compound } \\
\text { from } 189.80 \mathrm{~g} / \mathrm{h} \text { to } 188.20 \mathrm{~g} / \mathrm{h}\end{array}$ \\
\hline
\end{tabular}




\begin{tabular}{|c|c|c|c|c|}
\hline 6. & $\begin{array}{l}\text { Grinding (A13): } \\
\text { Assume there is } \\
1.41 \% \text { powder loss }\end{array}$ & $\begin{array}{l}\text { Grinding (A13): } \\
\text { Assume there is no } \\
\text { loss of powder }\end{array}$ & $\begin{array}{l}801 \text { tablets are produced } \\
\text { per hour packaged in } 100 \\
\text { Alu-Strips }\end{array}$ & $\begin{array}{l}\text { There is a slight change in the } \\
\text { phenolic compound in stream } 27 \\
\text { from } 81.12 \mathrm{~g} / \mathrm{h} \text { to } 79.98 \mathrm{~g} / \mathrm{h}\end{array}$ \\
\hline 7. & $\begin{array}{l}\text { Sieving (A13): } \\
\text { Assume there is } \\
0.83 \% \text { powder loss }\end{array}$ & $\begin{array}{l}\text { Sieving (A13): } \\
\text { Assume there is no } \\
\text { loss of powder }\end{array}$ & $\begin{array}{l}806 \text { tablets are produced } \\
\text { per hour packaged in } 101 \\
\text { Alu-Strips }\end{array}$ & $\begin{array}{l}\text { There is a slight change in the } \\
\text { phenolic compound in stream } 27 \\
\text { from } 81.12 \mathrm{~g} / \mathrm{h} \text { to } 80.45 \mathrm{~g} / \mathrm{h}\end{array}$ \\
\hline
\end{tabular}

From this work, it was also studied that with the decrease of TPC in the extract, the $\mathrm{IC}_{50}$ value increases. Therefore, to have a basis and assumption for the material balance calculation, an approximation was made to see the correlation between TPC and $\mathrm{IC}_{50}$ value, as can be seen on Figure 5. By using this plot, an approximation of the $\mathrm{IC}_{50}$ value of the $\mathrm{WH}$ tablet can be estimated, when the TPC is known. The $\mathrm{IC}_{50}$ value of the health supplement tablet containing WH extract having TPC of $6.31 \mathrm{mg}$ GAE is $480.24 \mathrm{ppm}$. This $\mathrm{IC}_{50}$ value is higher than the WH powder extract (which is $306.75 \mathrm{ppm}$ ) that indicates a lower antioxidant activity after being processed into a tablet. This value is considered to be reasonable since in a formulation of tablets, the API is mixed with different excipients that can lead to the lower antioxidant activity of the end-product.

However, to acquire a more accurate $\mathrm{IC}_{50}$ value of the WH tablet, further research must be conducted, and a validation of this approximation needs to be done. There is a strong possibility that the value of $\mathrm{IC}_{50}$ is not correlated only to the TPC value, which shows the amount of phenolic compounds content alone. The antioxidant activity of WH can also be resulted from the presence of other components contained in it, such as Vitamin C in a concentration of $0.18 \mathrm{mg} / \mathrm{g} \mathrm{WH}$, carotenoid $0.86 \mathrm{mg} / \mathrm{L}$, and $3.73 \mathrm{mg} / \mathrm{L}$ of chlorophyll [19].

\subsubsection{Simulation of Non-Ideal Manufacturing Process}

In the practice, non-ideal process conditions could occur, which will cause an alteration from the ideal material balance calculation made earlier. These nonideal scenarios could affect the yield of the phenolic content that leads to a change in the production capacity.

As can be seen in Table 5, a small change in the process could affect the entire production capacity and the yield of the total phenolic content. There are chances that scenarios in nonideal manufacturing processes might happen, so that it needs to be anticipated maintaining the efficiency of the machinery used, and the process operating procedures undertaken.

Table 6 shows that the production capacity is decreased from 812 tablets/h into 329 tablets/h if all 7 possible losses listed in Table 5 happen simultaneously. The production capacity is reduced by $59.48 \%$. The result of the unideal manufacturing process is inefficient since it took $30 \mathrm{~kg}$ to produce only 329 tablets which proves that the yield of the production is very low, which can bring harm to the economic sides of this operation. Therefore, the losses need to be anticipated, and the production process must avoid them from happening.

An adjustment can be done by selecting the machinery with better efficiency such as an integrated grinding and sieving machine in order to minimize the losses from the floating powder particles in the air. Another possibility is to choose freeze dryer over spray dryer for the pulverization process to prevent too much loss in the phenolic content of the $\mathrm{WH}$ as phenolic compound is known to be very heat sensitive [20]. However, further implications need to also be taken into consideration, as selecting freeze dry to replace the spray dryer might end up in a bigger energy requirement and could in the end also be a load to the production cost.

Table 6 Production capacity with all possible nonideal process conditions

\begin{tabular}{|c|c|c|c|}
\hline $\begin{array}{l}\text { Non-Ideal } \\
\text { Processes }\end{array}$ & $\begin{array}{l}\text { Ideal } \\
\text { TPC }\end{array}$ & $\begin{array}{l}\text { Non- } \\
\text { Ideal } \\
\text { TPC }\end{array}$ & $\begin{array}{c}\text { Producti } \\
\text { on } \\
\text { Capacity }\end{array}$ \\
\hline $\begin{array}{l}\text { Washing (A1): } \\
29.3 \% \text { TPC loss }\end{array}$ & $\begin{array}{c}189.80 \\
\mathrm{~g} / \mathrm{h}\end{array}$ & $\begin{array}{c}134.19 \\
\mathrm{~g} / \mathrm{h}\end{array}$ & \multirow{5}{*}{$\begin{array}{l}329 \\
\text { tablets/h, } \\
\text { packaged } \\
\text { in } 41 \\
\text { Alu-Strip }\end{array}$} \\
\hline $\begin{array}{l}\text { Cutting (A3): } \\
3 \% \text { of TPC loss }\end{array}$ & $\begin{array}{c}189.80 \\
\mathrm{~g} / \mathrm{h}\end{array}$ & $\begin{array}{c}129.09 \\
\mathrm{~g} / \mathrm{h}\end{array}$ & \\
\hline $\begin{array}{l}\text { Drying (A4): } \\
10 \% \text { of TPC loss }\end{array}$ & $\begin{array}{c}189.80 \\
\mathrm{~g} / \mathrm{h}\end{array}$ & $\begin{array}{c}116.18 \\
\mathrm{~g} / \mathrm{h}\end{array}$ & \\
\hline $\begin{array}{l}\text { Grinding \& Sieving } \\
\text { (A5): } 2.24 \% \text { of } \\
\text { TPC loss }\end{array}$ & $\begin{array}{c}189.80 \\
\mathrm{~g} / \mathrm{h}\end{array}$ & $\begin{array}{c}113.58 \\
\mathrm{~g} / \mathrm{h}\end{array}$ & \\
\hline $\begin{array}{l}\text { Grinding \& Sieving } \\
\text { (A13): } 2.24 \% \text { of } \\
\text { TPC loss }\end{array}$ & $\begin{array}{c}81.12 \\
\mathrm{~g} / \mathrm{h}\end{array}$ & $\begin{array}{c}32.82 \\
\mathrm{~g} / \mathrm{h}\end{array}$ & \\
\hline
\end{tabular}

\section{CONCLUSION}

The results of this research have shown that WH powder extract has a good potential to be used as an API in herbal supplements, for having high antioxidant activity and has been proven nontoxic. A conceptual design for the production process of health supplement containing WH extract conducted in this research suggested a production capacity of 812 tablets/h from 30 $\mathrm{kg} / \mathrm{h}$ fresh $\mathrm{WH}$ leaves, where each tablet is expected to show an antioxidant activity of $480.24 \mathrm{ppm}$. However, if a non-ideal processing operation happened which caused additional losses along the process, a decrease of production capacity could occur, down to an extreme value of 329 tablets/h. 


\section{REFERENCES}

[1] Istirokhatun $\mathrm{T}$, Rokhati $\mathrm{N}$, Rachmawaty R, Meriyani M, Priyanto S, Susanto H. Cellulose isolation from tropical water hyacinth for membrane preparation. Procedia Environmental Sciences. 2015 Jan 1;23:274-81.

[2] Jimmy, DI Widiputri, Gunawan P. Study of The Pharmacological Activity and Heavy Metal Content of Eichhornia crassipes Extract. Entrepreneurship and Technology 2018. 2018:85.

[3] Nugriani NO, Diah ID, Yusri S, MT SS. Antioxidant Stability Testing On Liquid And Powder Eichhornia Crassipes Extract. InIOP Conference Series: Materials Science and Engineering 2020 (Vol. 742, No. 1, p. 012019). IOP Publishing.

[4] Hamidi MR, Jovanova B, Panovska TK. Toxicological evaluation of the plant products using Brine Shrimp (Artemia salina L.) model. Maced pharm bull. 2014;60(1):9-18.

[5] Meyer BN, Ferrigni NR, Putnam JE, Jacobsen LB, Nichols DJ, McLaughlin JL. Brine shrimp: a convenient general bioassay for active plant constituents. Planta medica. 1982 May;45(05):31-4.

[6] Sulit JE, Atienza LM. Cytotoxic Effect of the Methanolic Extract of Selected Edible Weeds on Artemia salina Nauplii. J Nutr Res Food Sci 2020; 1. 2020 Sep 16;4.

[7] Orme B. Sample size issues for conjoint analysis studies. Sequim: Sawtooth Software Technical Paper. 1998.

[8] Anderson P. The Effect of Ethyl Alcohol on the Hatching Success of Artemia Salina-Winner of the 2009 Robert N. Hancock Memorial Scholarship for the best original technical paper written by a student on a topic in the fields of science or engineering (not peer reviewed). Journal of the IEST. 2009 Apr $1 ; 52(1): 9-19$.

[9] $\mathrm{Wu} \mathrm{W}$, Guo X, Huang M. Evaluation of acute toxicity potential of water hyacinth leaves. Toxicology and industrial health. 2014 Jun;30(5):426-31.

[10] Kline TJ. Modern test theory: assumptions, equations, limitations, and item analyses. Psychological Testing: A Practical Approach to Design and Evaluation. 2005:107-66.

[11] Rao P. Measuring consumer perceptions through factor analysis. In The Asian 2012, pp 28-23.

[12] Olowoyeye OI, Evbuomwan BO. Comparative analysis of the effect of size reduction on the drying rate of cassava and plantain chips. International
Journal of Geology, Agriculture and Environmental Sciences. 2014;2(4):20-7.

[13] Cha J, Gilmor T, Lane P, Ranweiler JS. Stability studies. InSeparation Science and Technology 2011 Jan 1 (Vol. 10, pp. 459-505). Academic Press.

[14] Szabó P, Zelko R, Antal I. The role of solid state characterization in predicting stability of solid dosage forms. Current pharmaceutical design. 2016 Sep 1;22(32):5019-28.

[15] Khaidir S, Murrukmihadi M, Kusuma AP. Formulasi tablet ekstrak kangkung air (Ipomoea aquatica F.) dengan variasi kadar amilum manihot sebagai bahan penghancur. Jurnal Ilmiah Farmasi. 2015;11(1):1-8.

[16] Pratiwi K. Formulasi Tablet Ekstrak Buah Pare (Momordica charantia L.) Dengan Variasi Konsentrasi Bahan Pengikat Gelatinsecara Granulasi Basah. digilib.uns.ac.id.

[17] Fahr A. Voigt's pharmaceutical technology. John Wiley \& Sons; 2018 Apr 23.

[18] Nadhi N, Pertiwi SP, Utomo GW, Chasanah U, Radjaram A. FORMULASI TABLET OBAT HERBAL PEGAGAN (CENTELLA ASIATICA L). Research Report. 2017 Nov 17.

[19] Kurniawan M, Izzati M, Nurchayati Y. Kandungan klorofil, karotenoid, dan vitamin $\mathrm{C}$ pada beberapa spesies tumbuhan akuatik. Anatomi Fisiologi. 2010;18(1):28-40.

[20] Chipurura B, Muchuweti M, Manditseraa F. Effects of thermal treatment on the phenolic content and antioxidant activity of some vegetables. Asian Journal of Clinical Nutrition. 2010;2(3):93-100. 